\title{
The Difference Platelet Lymphocyte Ratio and Thrombocyte Volume between Benign Compared to Carcinoma Thyroid Gland
}

\author{
Bambang Udji Djoko Rianto*, Rangga Putra Nugraha, Sagung R Indrasari and Anggoro Eka Raditya \\ Otorhinolaryngology, Head and Neck Surgery Department, Faculty of Medicine, Universitas Gadjah Mada/ DR. Sardjito General \\ Hospital,Yogyakarta, Indonesia \\ *Corresponding author: Bambang Udji Djoko Rianto, Otorhinolaryngology, Head and Neck Surgery Department, Faculty of \\ Medicine, Universitas Gadjah Mada/ DR. Sardjito General Hospital Yogyakarta 55281, Indonesia
}

\section{ARTICLE INFO}

Received: 隠 June 14, 2019

Published: 慧 June 26, 2019

\section{Citation: Bambang Udji Djoko R, Rangga} Putra N, Sagung R Indrasari, Anggoro Eka R. The Difference Platelet Lymphocyte Ratio and Thrombocyte Volume between Benign Compared to Carcinoma Thyroid Gland. Biomed J Sci \& Tech Res 19(2)2019. BJSTR. MS.ID.003261.

Keywords: Thrombocyte; Lymphocyte; Inflammation; Thyroid Nodule; Thyroid Carcinoma

\section{ABSTRACT}

Background: The inflammatory response is triggered by circulating cytokines, chemokines, which are released by malignant cells in blood circulation, cause systematic alterations such as neutrophilia, thrombocytosis and lymphocytopenia.

Objective: To determine the difference thrombocyte/lymphocyte ratio and thrombocyte volume between thyroid nodule and carcinoma.

Methods: This research was a case-control study at Dr. Sardjito General Hospital, Yogyakarta, between early January 2015 until the end 2017. The inclusion criteria case group was thyroid carcinoma based on AJCC 2012, while the control group was benign thyroid nodule, underwent thyroidectomy. The exclusion criteria case and control groups were: 1) patients suffering from thyroid hormone disorders requiring therapy before thyroidectomy, 2) patients receiving thyroid suppression therapy prior to thyroidectomy. Pathological anatomy, thrombocyte-lymphocyte ratio and mean thrombocyte volume were examined before thyroidectomy. The sample size each group was 36 samples.

Results: Female were more dominant than men patients. There were $63(87.5 \%)$ thyroid nodule and 31 (49.2\%) thyroid carcinoma. In thyroid carcinoma, 20 (55.5\%) patients were dominant in 45 compared less 45 than years old. Papillary thyroid carcinoma found in 32 (88.9\%) patients. In the thyroid nodule the platelet-lymphocyte ratio was 56.72 until 206.79 and platelet volume was $7.5 / \mathrm{mL}$ until $11.5 / \mathrm{mL}$, while in thyroid carcinoma between 100.31 until 211.88 and 9.4 until $13.4 / \mathrm{mL}$ respectively.

Conclusion: It can be concluded that in the thyroid nodule the mean plateletlymphocyte ratio was 122.252 and the mean platelet volume was $10.042 / \mathrm{mL}$, while in the thyroid carcinoma was 145.514 and $10.525 / \mathrm{mL}$ respectively. This difference is statistically significant.

\section{Introduction}

Among adults, thyroid nodules occur in $19-67 \%$, while the incidence is higher in women and the elderly, but only $5-15 \%$ are in the form of thyroid cancer [1]. Thyroid nodules are a common condition and their clinical importance is to distinguish malignancy (4.0-6.5\% of all thyroid nodules), evaluate the functional status of the nodule and whether it creates suppression symptoms [2].

Fine Needle Aspiration (FNA) is an early diagnostic tool in thyroid cancer screening and helps to avoid unnecessary surgery.
FNA has good sensitivity and specificity for thyroid cancer, with $84 \%-93 \%$ for sensitivity and $75 \%-99 \%$ for specificity. There are around $15 \%-30 \%$ of FNA results that are uncertain. Since a biopsy cannot be performed on the thyroid nodule to determine a malignancy, another modality of examination is needed [3].

Various inflammatory cell mediators and effectors are important constituents of the local tumor environment. An oncogenic change will create an inflammatory microenvironment which will then 
stimulate further tumor formation. The inflammation works in the process of proliferation and survival of malignant cells, trigger the occurrence of angiogenesis and metastasis, damaging the adaptive immune response, and changing the response to various hormones and chemotherapeutic agents [4].

The inflammatory response is triggered by circulating cytokines and chemokines, which are released by malignant cells. As a result, systemic changes such as neutrophilia, thrombocytosis and lymphocytopenia occur. Several investigations have shown that platelets not only support the occurrence of primary tumor cell growth via angiogenesis but also are associated with tumor metastasis through an immune system avoidance mechanism and inhibition of the lysis of tumor cells by natural killer cells [5].

Systemic inflammation due to cancer causes the expression of several inhibiting mediators, especially Interluekin-10 (IL-10) and Transforming Growth Factor- $\beta$ (TGF- $\beta$ ). This response results in immunosuppressive effects which then cause lymphopenia and lymphocyte dysfunction [6].

Average Platelet Volume (APV) is the initial indicator of platelet activation, which shows the average platelet size that reflects average platelet production. Relatively large and new platelets are more reactive and produce more thrombogenic factors $[7,8]$. The Platelet-Lymphocyte Ratio (PLR) and APV in thyroid nodules is expected to help predict the risk of malignancy, which can aid in the selection of cases for surgery or the decision to treat only conservatively. Currently, biocellular markers can be used to help determine whether thyroid nodules are benign or malignant and thus affect subsequent management $[1,9]$. Cell proliferation alone cannot cause cancer, but continuous cell proliferation in an environment rich in inflammatory cells, growth factors, activated stroma, and agents that cause damage to Deoxyribonucleic Acid (DNA), will obviously strengthen and/or trigger the risk of malignant neoplasms. Proliferative cells that maintain conditions of DNA damage and/or mutagenic damage (for example, cells capable of initiating themselves) will continue to multiply in a microenvironment rich in inflammatory cells and growth factors that support their growth [10].

However, this examination modality is not available in all hospitals, so researchers identified other modalities that could be used to predict the risk of malignancy in thyroid nodules, namely PLR and PV examinations. In addition, PLR and PV can also confirm benign FNA results in thyroid tests that have false negative values from $2 \%$ to $10 \%$ [3]. This study aimed to determine the difference in mean Platelet-Lymphocyte Ratio (PLR) and mean Platelet Volume (PV) between malignant thyroid tumors compared to benign thyroid nodules.

\section{Methods}

This study used a case-control design. The study was conducted at Otorhinolaryngology Department, Clinical Pathology Department and Department of Pathology Anatomy Faculty of Medicine Universitas Gadjah Mada/ Dr. Sardjito General Hospital (RSUP) Yogyakarta from early January 2016 until the end of April 2018. The study started after receiving approval from the Medical and Health Research Ethics Committee (MHREC) Faculty of Medicine, Public Health and Nursing, Universitas Gadjah Mada, Yogyakarta, Indonesia under number KE/FK/05/5/ EC/2018.

The research subjects of this study were patients with malignant thyroid nodules as the case group and patients with benign thyroid nodules in the control group. The inclusion criteria for case group patients were:

a) All cases of malignant thyroid nodules were confirmed by laboratory tests and anatomical pathology and received surgery at RSUP dr. Sardjito,

b) The results of fine needle aspiration showed no metastasis, and

c) Patient agreed to participate in research by completing an informed consent form.

The exclusion criteria were:

1) Cases of malignant thyroid nodules with infectious disease, and

2) Cases of large needle biopsies without anatomical pathology results.

The inclusion criteria for the control group were:

a. All cases of benign thyroid nodules based on the results of anatomical pathology examination and laboratory tests and operations at RSUP Dr. Sardjito Yogyakarta, and

b. Agreed to participate in research by completing an informed consent form.

The exclusion criteria were:

1) Benign thyroid nodule cases with infectious disease, and

2) Cases of large needle biopsies without anatomical pathology results. Sample size was calculated using hospitalbased study sample size formulation for case-control study with error type I $(\alpha) 5 \%$ one-tailed hypothesis, and error type II ( $\beta$ ) $20 \%$. The recommended sample size for each group was 36 samples. All patients received preoperative examinations of the Platelet-Lymphocyte Ratio (PLR), Platelet Volume (PV), and postoperative anatomical pathology tests at Dr. Sardjito General Hospital.

Characteristic data of research subjects are presented as proportion, mean and standard deviation. To assess the difference in distribution, such as sex and educational level chi square and Fisher's Exact tests were used, while to assess the mean difference such as age independent $t$ test was used when the data had normal 
distribution and Mann Whitney test if the data had no normal distribution. Correlation was assessed by the Spearman and Pearson method.

\section{Results}

Table 1 shows there were 63 (87.5\%) female and 9 (12.5\%) male research subjects participated in this research. Based on the age grouping of research subjects, 41 (56.9\%) were in the age group $<45$ years while $31(43.1 \%)$ in the age group $\geq 45$ years. In the age group $<45$ years there were $25(69.4 \%)$ patients with benign thyroid nodules and 16 (44.4\%) with thyroid carcinoma, whereas in the age group 45 years, there were 11 (30.6\%) patients with benign thyroid nodules and 20 (55.6\%) with thyroid carcinoma. This difference was statistically significant $(p=0.032)$.

Table 1: Characteristics of research subjects.

\begin{tabular}{|c|c|c|c|c|c|}
\hline \multicolumn{3}{|c|}{ Variable } & $\begin{array}{c}\text { Benign thyroid } \\
\text { nodule (\%) }\end{array}$ & $\begin{array}{c}\text { Thyroid carcinoma } \\
\text { (\%) }\end{array}$ & $P$ value \\
\hline \multirow{4}{*}{ Sex } & Male & $9(12.5 \%)$ & $4(11.1)$ & $5(13.9)$ & \multirow{2}{*}{$1^{\mathrm{a}}$} \\
\hline & Female & $63(87.5 \%)$ & $32(88.9 \%)$ & $31(86.1 \%)$ & \\
\hline & $<45$ & $41(56.9 \%)$ & $25(69.4 \%)$ & $16(44.4 \%)$ & \multirow{2}{*}{$0.032^{\mathrm{b}}$} \\
\hline & $\geq 45$ & $31(43.1 \%)$ & $11(30.6 \%)$ & $20(55.6 \%)$ & \\
\hline \multirow{3}{*}{ Age (year old) } & Minimal & 16 & 16 & 16 & \multirow{3}{*}{$0.2^{\mathrm{c}}$} \\
\hline & Maximal & 78 & 78 & 73 & \\
\hline & Mean & 43 & 40.67 & 45.33 & \\
\hline \multirow{7}{*}{ Bethesda classification } & Not inspected & 42 & $24(57.1 \%)$ & $18(42.9 \%)$ & \\
\hline & $\mathrm{I}$ & 2 & $2(100 \%)$ & $0(0 \%)$ & \\
\hline & II & 6 & $4(66.7 \%)$ & $2(33.3 \%)$ & \\
\hline & III & 0 & $0(0 \%)$ & $0(0 \%)$ & \\
\hline & IV & 10 & $4(40 \%)$ & $6(60 \%)$ & \\
\hline & $\mathrm{V}$ & 9 & $2(22.2 \%)$ & $7(77.8 \%)$ & \\
\hline & VI & 3 & $0(0 \%)$ & $3(100 \%)$ & \\
\hline
\end{tabular}

Note: $a=$ Fisher Exact Test; $b=$ Chi Square Test; $c=$ Kolmogorov-Smirnov Test.

Table 2 shows all thyroid carcinomas in research subjects, 32 (88.9) papillary types, $3(0.8)$ follicular and $1(0.3)$ anaplastic sarcomatoid. Table 3 shows that the platelet-lymphocyte ratio (PLR) was obtained in wide variations with a minimum number of 56.72 until 206.79 in the benign thyroid nodule group while the carcinoma thyroid nodule group ranged from 100.31 until 211.88. This difference was statistically significant $(\mathrm{p}=0.07)$. The Platelet Volume (PV) was obtained at a minimum value of 7.5 until 11.5 to 13.4 in the benign thyroid nodule group while the patients with carcinoma thyroid nodule ranged from 9.4 until 13.4. This difference was statistically significant $(p=0.031)$.

Table 2: Thyroid carcinoma type.

\begin{tabular}{|c|c|}
\hline Type & N (\%) \\
\hline Papillary & $32(88.9)$ \\
\hline Follicular & $3(0.8)$ \\
\hline Anaplastic Sarcomatoid & $1(0.3)$ \\
\hline
\end{tabular}

Table 3: The PLR and PV in benign thyroid nodules and thyroid carcinoma.

\begin{tabular}{|c|c|c|c|c|}
\hline & Variable & $\begin{array}{c}\text { Benign thyroid } \\
\text { nodule }\end{array}$ & $\begin{array}{c}\text { Carcinoma thyroid } \\
\text { nodule }\end{array}$ & \multirow{p}{*}{ value } \\
\hline \multirow{3}{*}{ PLR } & Minimal & 56.72 & 100.31 & \\
\cline { 2 - 4 } & Maximal & 206.79 & 211.88 & \multirow{2}{*}{$0.007^{\mathrm{a}}$} \\
\cline { 2 - 4 } & Mean & 122.252 & 145.514 & \\
\hline
\end{tabular}

\begin{tabular}{|c|c|c|c|c|}
\hline \multirow{3}{*}{ PV } & Minimal & $7.5 / \mathrm{mL}$ & $9.4 / \mathrm{mL}$ & \multirow{2}{*}{$0.031^{\mathrm{b}}$} \\
\cline { 2 - 4 } & Maximal & $11.5 / \mathrm{mL}$ & $13.4 / \mathrm{mL}$ & \\
\cline { 2 - 4 } & Mean & $10.042 / \mathrm{mL}$ & $10.525 / \mathrm{mL}$ & \\
\hline
\end{tabular}

Note: $\mathrm{a}=$ Mann Whitney U Test; $\mathrm{b}=\mathrm{T}$-test; $\mathrm{PV}=$ average platelet volume; PLR= platelet-lymphocyte ratio.

Table 4 show the correlation between PLR and PV benign nodule compared to carcinoma of thyroid gland. This research study obtained cut-off point PLR was 129.5574 and PV was 10.35/ $\mathrm{mL}$ to distinguish between benign nodule compared to carcinoma of thyroid gland.

Table 4: PLR and PV between benign and carcinoma thyroid nodules.

\begin{tabular}{|c|c|c|c|c|}
\hline Variable & $\begin{array}{c}\boldsymbol{p} \\
\text { value }\end{array}$ & $\begin{array}{c}\text { Coefficient } \\
\text { correlation }\end{array}$ & AUC value & Cut-off point \\
\hline PLR & $0.007^{\mathrm{c}}$ & $0.321^{\mathrm{d}}$ & $\begin{array}{c}68.5 \% \\
(95 \% \mathrm{CI}: 56 . \\
\%-80.8 \%)\end{array}$ & 129.5574 \\
\hline PV & $0.031^{\mathrm{a}}$ & $0.255^{\mathrm{b}}$ & $\begin{array}{c}57.9 \% \\
(95 \% \text { CI: } 44.5 \%- \\
71.4 \%)\end{array}$ & $10.35 / \mathrm{mL}$ \\
\hline
\end{tabular}

Note: $\mathrm{a}=\mathrm{t}$-test; $\mathrm{b}=$ Pearson Correlation; $\mathrm{c}=$ Mann Whitney U Test; $\mathrm{d}=$ Spearman Correlation; $\mathrm{AUC}=$ Area Under the Curve; $\mathrm{CI}=$ Confidence Interval 


\section{Discussion}

In this study thyroid nodules were more common in women $(87.5 \%)$ than in men $(12.5 \%)$. The youngest age in this study was 16 years and the oldest 78 years out of 72 cases of thyroid nodules (Table 1). These results are consistent with previous studies that found thyroid nodules are more common in women and their frequency increases with age, lack of iodine consumption and radiation exposure [11]. Another study showed that the incidence of thyroid cancer is around 3-4 times higher in women [12].

Estrogen is thought to be associated with an increased incidence of thyroid nodules and thyroid cancer. Thyroid tissue expresses estrogen receptors, both estrogen and $\beta$ receptors. Previous research has found significant increases in the expression of $17 \beta$-estradiol receptors. Estrogen receptors are intracellular receptors that play a role in transcription factors. Estrogen increases the growth of benign and malignant thyroid nodules by binding to estrogen receptor nuclei through activation of mitogen protein kinase pathways (MAP) thereby mediating mitogenesis [13].

Table 1 in this study shows 20 cases (55.5\%) of malignant thyroid nodules aged $\geq 45$ years and 11 cases (30.5\%) of benign nodules and the distribution is statistically different $(p=0.032)$. This result is in accordance with the incidence of malignancy cases which increases with age. Most of these tumors occur in the 3rd to 6th decades of life (Katoh, 2015). This pattern is presumably possible because of changes in normal thyroid tissue and a decrease in the immune system that is in line with increasing age [14].

Thyroid cancer mainly originates from follicular cells with 3 main types: namely, papillary thyroid carcinoma, follicular thyroid carcinoma and anaplastic thyroid carcinoma. Papillary thyroid carcinoma is the most common type with $85-90 \%$ of all cases of thyroid malignancy followed by follicular thyroid carcinoma in $5-10 \%$ of cases [12]. Thyroid nodules can be caused by a variety of conditions: benign (colloidal nodules, Hashimoto thyroiditis, simple cysts or bleeding cysts, follicular adenomas, and subacute thyroiditis) and malignancies: papillary cancer, follicular cancer, Hurthle cell cancer (oncocytic), anaplastic cancer, cancer medullaris, thyroid lymphoma, and metastasis [2].

In this study, the results also showed a similar pattern where papillary carcinoma dominated with $88.9 \%$, followed by follicular carcinoma as much as $0.8 \%$ and anaplastic sarcoid carcinoma with $0.3 \%$ (Table 2). There were significant differences in PV and PLR values statistically in benign and malignant thyroid nodules ( $p=0.031$ and 0.007 , respectively) (Table 4). Results also found correlations between PLR and PV with the risk of malignancy in thyroid nodules (each correlation coefficient: 0.321 and 0.255 , respectively).

Another study reported that there was statistically significant difference of neutrophil/lymphocyte ratio and platelet-lymphocyte ratio between benign and malignant thyroid especially in multifocal tumours [15-17]. Others study found that platelets contribute to tumor growth, invasion and angiogenesis. Platelets protect tumor cells from destruction by NK cells, thereby facilitating metastasis $[18,19]$. Another study reported that there is no significant relationship between papillary thyroid cancer and inflammatory hematological parameters including the eutrophil/ lymphocyte (N/L) ratio and Mean Platelet Volume (MPV) [20], but the other study obtained that the Neutrophil/Lymphocyte Ratio (NLR) is a simple index of systemic inflammatory response and has been shown to be a prognostic indicator in some types of cancer [21]. On the contrary, there is plenty of evidence to suggest that endothelial tumors and cell are influenced by VEGF, growth factors, secretion of interleukins secreted by platelets. Platelets play an important role in the metabolism of cancer pathogenesis with its angiogenic, metastatic and proteolytic activities [22].

\section{Conclusion}

Based on the results of this study, it can be concluded that there are statistically significant differences in the mean ratio of platelet lymphocytes and mean platelet volume between benign thyroid nodules compare to malignant thyroid nodules.

\section{Acknowledgement}

We are gratefully indebted to our study participants in Yogyakarta. We also express our gratitude to internal medicine clinic Dr. Sardjito General Hospital Yogyakarta Staff, Dr. Sardjito General Hospital, Clinical Pathology Department and Department of Pathology Anatomy Staff Faculty of Medicine Universitas Gadjah Mada/ Dr. Sarajevo General Hospital and all research assistants (ENT Residences and Nurses) who participated in this research.

\section{References}

1. Cooper DS, Doherty GM, Haugen BR, Kloos RT, Lee SL, et al. (2009) Revised American thyroid association management guidelines for patients with thyroid nodules and differentiated thyroid cancer. Thyroid 19(11): 1167-1214.

2. Tamhane S, Gharib H (2016) Thyroid nodule update on diagnosis and management. Clin Diabetes Endocrinol 2(17): 1-10.

3. Brophy C, Stewart J, O’Donovan N, McCarthy J, Murphy M, et al. (2015) Impact of microcalcifications on risk of malignancy in thyroid nodules with indeterminate or benign cytology. Otolaryngol Head Neck Surg 154(1): 46-51.

4. Mantovani A, Allavena P, Sica A, Balkwill F (2008) Cancer-related inflammation. Nature 454: 436-444.

5. Jiang K, Lei J, Chen W, Gong Y, Luo H, et al. (2016) Association of the preoperative neutrophil-to-lymphocyte and platelet-to-lymphocyte ratios with lymph node metastasis and recurrence in patients with medullary thyroid carcinoma. Medicine 95(40): 1-6.

6. Miglani RK, Bhateja N, Bhat RS, Kumas KVA (2013) Diagnostic role of Platelet Lymphocyte Ratio (PLR) in pancreatic head masses. Indian J Surg 75(1): 4-9.

7. Baldane S, Ipekci SH, Sozen M, Kebapcilar L (2015) Mean platelet volume could be a possible biomarker for papillary thyroid carcinoma. Asian Pac J Cancer Prev 16: 2671-2674.

8. Bayhan Z, Zeren S, Ozbay I, Kahraman C, Yaylak F, et al. (2016) Mean platelet volume as a biomarker for thyroid carcinoma. Int Surg 101: 5053. 
9. Jonas T Johnson, Clark A Rosen (2014) Bailey's Head \& Neck SurgeryOtolaryngology Review, ( $5^{\text {th }}$ Edn). Lippincott Williams \& Wilkins pp. 2115-2130

10. Caussens LM, Werb Z (2002) Inflammation and cancer. Nature 420 (6917): 860-867.

11. Paschke R, Lincke T, Müller SP, Kreissl MC, Dralle H, et al. (2015) The treatment of well-differentiated thyroid carcinoma. Dtsch Arztebl Int 112: 452-458.

12. Katoh H, Yamashita K, Enomoto T, Watanabe M (2015) Classification and general consideration of thyroid cancer. Ann Clin Pathol 3(1): 1-9.

13. Manole D, Schilddknecht B, Gosnell B, Adams E, Derwahi M (2001) Estrogen promotes growth of human thyroid tumor cells by different molecular mechanisms. J Clin Endocrinol Metab 86(3): 1072-1077.

14. Haymart MR (2009) Understanding the relationship between age and thyroid cancer. The Oncologist Express 14(3): 216-221.

15. Ozmen S, Timur O, Calik I, Altinkaynak K, Simsek E, et al. (2017) Neutrophil-lymphoyte ratio (NLR) and Platelet Lymphocyte Ratio (PLR) may be superior to C-Reactive Protein (CRP) for predicting the occurrence of differentiated thyroid cancers. Endocr Regul 51(3): 131136.

16. Machairas N, Kostakis ID, Prodromidou A, Stamopoulos P, Feretis T, et al (2017) Trends in white blood cell and platelet indices in a comparison of patients with papillary thyroid carcinoma and multinodular goiter do not permit differentiation between the conditions. J Endocr Res 42(4): 311-317.

\section{ISSN: 2574-1241}

DOI: 10.26717/BJSTR.2019.19.003261

Bambang Udji Djoko Rianto. Biomed J Sci \& Tech Res

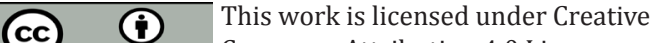

Submission Link: https://biomedres.us/submit-manuscript.php
17. Manatakis DK, Tseleni-Balafouta S, Tzelves T, Balalis D, Tzortzopoulou A, et al. (2018) Diagnostic accuracy of preoperative neutrophil-tolymphocyte and platelet-to-lymphocyte ratios in detecting occult papillary thyroid microcarcinomas in benign multinodular goitres. J Thyroid Res p. 1-6.

18. Templeton AJ, Ace O, McNamara MG, Al-Mubarak M, Vera-Badillo FE, et al. (2014) Prognostic role of platelet to lymphocyte ratio in solid tumors: A systematic review and meta-analysis. Cancer Epidemiol Biomarkers Prev 23(7): 1204-1213.

19. Yaylaci S, Tosun O, Sahin O, Genc AB, Aydin E, et al. (2016) Lack of variation in inflammatory hematological parameters between benign nodular goiter and papillary thyroid cancer. Asian Pac J Cancer Prev 17(4): 2321-2323.

20. Kocer D, Karakukcu C, Karaman H, Gokay F, Bayram F (2015) May the neutrophil/lymphocyte ratio be a predictor in the differentiation of different thyroid disorders? Asian Pac J Cancer Prev 16(9): 3875-3879.

21. Wen W, Wu P, Li J, Wang H, Sun, J, et al. (2018) Predictive values of the selected inflammatory index in elderly patients with papillary thyroid cancer. Transl Med 16 (261): 1-7.

22. Kim SM, Kim EH, Kim BH, Kim JH, Park SB, et al. (2015) Association of the preoperative neutrofil-to-lymphocyte count ratio and plateletto-lymphocyte count ratio with clinicopathological characteristics in patients with papillary thyroid cancer. Endocrinol Metab 30: 494-501.

$\begin{array}{ll}\text { BIOMEDICAL } & \text { Assets of Publishing with us } \\ \text { RESEARCHES } & \text { - Global archiving of articles } \\ & \text { - Immediate, unrestricted online access } \\ \end{array}$

